\title{
DRAMA „NOULUI PUBLIC" SAU CRITICA JURISPRUDENTTEI CJUE PRIVIND COMUNICAREA PUBLICĂ A CREAȚIILOR INTELECTUALE PRIN FURNIZAREA DE HIPERLINKURI
}

\author{
DOI:10.24193/SUBBiur.62(2017).3.5 \\ Published Online: 2017-09-30 \\ Published Print: 2017-09-30
}

Réka KIS*

\begin{abstract}
The Drama of the "New Public" Theory in the Case Law of the CJUE regarding the communication to the public of copyright works - The Court of Justice of the European Union has delivered several preliminary rulings on the interpretation of the right to communication to the public of copyright works. The present article examines the case law of the Court regarding the act of communication to the public in the form of posting hyperlinks and the theory of the "new public" and argues that this theory, as well as the subsequent theories and criteria adopted by the Court with the purpose of correcting the deficiencies of the former, are incompatible with the principles of copyright law and are in conflict with the international norms and the provisions of the Infosoc Directive.

Therefore, the first section of the study sums up the international and European legal background of the right of communication to the public, emphasizing that the international conventions are binding for all their members including the EU. The consequent sections present and analyze those judgements of the Court of Justice which have contributed to the establishment or maintenance of the 'new public' theory, in spite of the reproving opinions of numerous copyright specialists. Regarding the widely spread use of hyperlinks and the practical implications of the misinterpretation of the communication to the public, such as the exhaustion of the author's right or the introduction of formalities for copyright protection, the author of the article hopes that the present study will be of interest not only for researches of copyright law, but for legal practitioners, as well.
\end{abstract}

Keywords: copyright, Berne Convention, WCT, Infosoc directive, communication to the public, new public theory.

Cuvinte cheie: drept de autor, Convenția de la Berna, WCT, directiva Infosoc, dreptul la comunicare publică, teoria noului public.

\section{Introducere}

Unul dintre cele mai utile instrumente ale acquis-ului Uniunii Europene este procedura trimiterii preliminare, prin care Curtea de Justiție a Uniunii Europene are posibilitatea de a asista instanțele naționale în interpretarea corectă a legislației UE ${ }^{1}$ și în 
unele situații, chiar și de a armoniza legislațiile statelor membre. În acest sens, Curtea adoptă hotărâri obligatorii de interpretare a tratatelor și a legislației secundare a Uniunii. Dezavantajul acestei competențe îl constituie faptul că instanța europeană este nevoită să se pronunțe în toate domeniile acoperite de legislația UE, o arie ce cuprinde o gamă largă de domenii, dintre care unele necesită o specializare aparte, cum sunt și dreptul de autor sau dreptul internetului.

Astfel, Curtea de Justiție a Uniunii Europene s-a confruntat cu o provocare considerabilă atunci când a fost solicitată să decidă dacă postarea unor hiperlinkuri pe o pagină de web constituie comunicarea publică a unei opere protejate prin dreptul de autor în raport cu reglementarea UE și cu respectarea tratatelor internaționale ratificate de UE și de statele sale membre. Pe parcursul deliberării, Curtea era nevoită, pe de-o parte, să asigure o protecție ridicată drepturilor de autor și, pe de altă parte, să conserve libertatea și funcționarea neștirbită a internetului, al cărui element important îl reprezintă hiperlinkurile. Hiperlinkurile simple, care conduc utilizatorii la pagina principală a website-ului, linkurile profunde, care direcționează cititorii către o altă pagină decât cea principală, linkurile realizate prin tehnica de încadrare (framing) sau încorporare (embedding) ${ }^{2}$, precum toate celelalte tipuri de linkuri existente sau în curs de dezvoltare sunt indispensabile pentru funcționarea optimă internetului. Din perspectiva utilizatorilor de internet, linkurile pot fi o metodă de citare în cursul cercetării științifice, o modalitate de auto-exprimare pe rețelele de socializare sau un instrument comercial folosit cu ocazia încadrării unei reclame publicitare pe un blog. Indiferent de modalitatea utilizat[, specificitatea hiperlinkurilor, din perspectiva dreptului de autor este că furnizorul linkului nu efectuează o transmitere a operei, ci direcționează utilizatorul către adresa unde se găsește opera protejată. În prezența acestor condiții specifice și a intereselor deseori antagonice ale diferitelor titulari de drepturi, Curtea a avut sarcina de desluși înțelesul dispozițiilor directivei Infosoc referitoare la dreptul comunicării publice. Curtea a aplicat diferite metode de interpretare a noțiunii de comunicare publică, care însă sunt deseori inconsistente, impredictibile și în contradicție cu normele internaționale ale dreptului de autor. După părerea unor autori, explicația rezidă (și) în lipsa de expertiză specializată a judecătorilor. ${ }^{3}$

În studiul de față vom încerca să analizăm evoluția jurisprudenței Curții privitoare la această problematică. Înainte de a trece la analiza critică a hotărârilor relevante, vom prezenta cadrul juridic internațional și cel dezvoltat de UE cu privire la comunicarea publică a operelor protejate de dreptul de autor.

\section{Reglementarea dreptului la comunicare publică în dreptul internațional și dreptul Uniunii Europene}

Dreptul la comunicare publică este un drept patrimonial exclusiv al autorului, consacrat pe plan internațional prin Convenția de la Berna, ${ }^{4}$ în forma unor prevederi specifice, fragmentate, care, ulterior modificărilor Convenției și în urma încheierii "tratatelor internetului" s-a dezvoltat într-un drept general și cupriznător. ${ }^{5}$

Convenția de la Berna, adoptată înainte de apariția societății informaționale și utilizarea cotidiană a internetului, nu reușește să satisfacă cerințele protecției dreptului de 
autor impuse de mediul digital. În varianta sa actuală, Convenția reglementează două categorii de drepturi privind comunicarea publică. Astfel, prevede, pe de-o parte, dreptul autorului de a autoriza orice tip de comunicare a operelor dramatice, dramatico-muzicale şi muzicale (art. 11), operelor literare recitate (art. $11^{\text {ter }}$ ) și a operelor cinematografice adaptate (art. 14 (1)(ii)), or, asigură un drept general de a autoriza comunicarea publică, indiferent de modalitatea comunicării, însă numai cu privire la anumite tipuri de operă. lar pe de altă parte, Convenția asigură dreptul exclusiv și general al autorului de a autoriza radiodifuzarea oricărui tip de operă (art. $11^{\text {bis}) . ~}{ }^{6}$ Prin urmare, dispozițiile Convenției nu acoperă întreaga paletă a modalităților de comunicare publică. De exemplu, Convenția nu reglementează comunicarea publică a programelor de calculator sau a operelor de artă vizuală, cu excepția modalităților enumerate de art. 11bis din Convenție și nu reglementează dreptul autorilor de a autoriza actele de transmitere a operelor "la cerere”, i.e. cazurile în care publicul poate alege locul și momentul recepției operelor protejate. ${ }^{7}$

În vederea remedierii acestor lacune, Organizația Mondială a Proprietății Intelectuale (în continuare OMPI) a elaborat două tratate internaționale, supranumite ",tratatele internet" 8 , care constituie de fapt o extensie a Convenției de la Berna. Acestea sunt Tratatul Organizației Mondiale a Proprietăţii Intelectuale privind dreptul de autor (în continuare WCT) și Tratatul OMPI privind interpretările, execuţiile şi fonogramele (în continuare: WPPT) ${ }^{9}$.

Obiectul principal al WCT și WPPT este protecția operelor și a drepturilor titularilor de drepturi, respectiv a drepturilor conexe în mediul digital, conservând un echilibru între drepturile autorilor și diverse interese ale publicului, precum educația, cercetarea științifică și accesul la informații ${ }^{10}$. Totodată, articolul 8 al WCT și art. 10 al WPPT extinde - fără a prejudicia articolele relevante din Convenția de la Berna - definiția dreptului la comunicare publică. În acest sens, tratatele înzestrează titularul de drepturi cu dreptul de a autoriza orice comunicare publică a operelor sale ${ }^{11}$ prin mijloace cu fir sau fără fir, inclusiv de a controla folosirea individualizată și interactivă a operelor sale, sub denumirea de "punere la dispoziția publicului" ${ }^{\prime 2}$. Punerea la dispoziția publicului nu presupune în mod obligatoriu transmiterea operei la utilizator, este de ajuns ca acesta să aibă acces la operă în locul și la momentul ales în mod individual de el.

Directiva nr. 2001/29/CE, cunoscută sub denumirea de directiva Infosoc a preluat și a transpus în dreptul comunitar multe dintre prevederile noilor tratate OMPI. ${ }^{13}$ Directiva a fost adoptată de Comunitățile Europene pe baza art. 95 din TCE (art. 114 din TFUE) ca și o măsură necesară instituirii și asigurării funcționării pieței interne și este un instrument de armonizare a legislațiilor statelor membre în domeniul dreptului de autor. Directiva promovează păstrarea unui echilibru între protecția drepturilor de autor, dezvoltarea societății informaționale și drepturile și interesele diverselor categorii de titulari de drepturi, scopul final fiind buna funcționare a pieței interne. ${ }^{14}$

În ceea ce privește dreptul la comunicare publică, alineatul (1) al articolului 3 asigură autorilor dreptul exclusiv de a autoriza sau de a interzice orice comunicare publică a operelor lor, prin cablu sau fără cablu, inclusiv punerea la dispoziția publicului a operelor, astfel încât oricine să poată avea acces la acestea din orice loc și în orice moment. ${ }^{15}$ Alineatul 2 
asigură un drept asemănător titularilor de drepturi conexe, iar alineatul 3 al aceluiași articol subliniază că drepturile menționate la alineatele precedente nu se epuizează.

Uniunea Europeană, ca și membră a Organizației Mondiale de Comerț și prin urmare, a Acordului TRIPS ${ }^{16}$ este obligată prin art. 9 alin.(1) al acestuia din urmă să respecte prevederile Convenției de la Berna. Iar prin decizia 2000/278/CE ${ }^{17}$, Comunitatea a adoptat și „tratatele internetului".

\section{Prima cauză cu hiperlinkuri: Svensson}

Prima cauză în care Curtea s-a pronunțat cu privire la interpretarea actului de comunicare publică în forma postării de hiperlinkuri a fost cauza Svensson ${ }^{18}$. În litigiul principal, articolele de presă ale reclamanților-jurnaliști au fost publicate în ziarul Göteborgs-Posten și pe site-ul Göteborgs-Posten, unde puteau fi accesate în mod liber de orice persoană conectată la internet. Cu alte cuvinte, că accesul la opere nu a fost restricționat în niciun fel, precum prin instalarea unui sistem de logare sau obligarea la plata unor redevențe. Retriever Sverige, pârâtul din litigiul principal, exploata un site internet, care furniza clienților săi liste cu hiperlinkuri, care făceau legătura cu site-uri jurnalistice, unde erau publicate diferite articole protejate prin dreptul de autor. Pe lista acestor linkuri se afla și site-ul Göteborgs-Posten ${ }^{19}$, motiv pentru care reclamanții au chemat în judecată societatea Retriever Sverige, solicitându-i plata unor despăgubiri. Ei au susținut că Retriever Sverige, prin postarea hiperlinkurilor, a adus atingere dreptului lor exclusiv de a pune sau autoriza punerea la dispoziția publicului a articolelor care le aparțineau. ${ }^{20}$ Retriever Sverige a susținut în apărare, că furnizarea unor liste cu linkuri de internet nu constituie un act susceptibil să afecteze drepturile de autor, întrucât prin simpla furnizare a adreselor de web nu s-a efectuat de fapt o transmitere a operelor protejate, acțiunea sa limitându-se la indicarea adreselor de web unde se regăsesc operele. ${ }^{21}$

Instanța de apel a suspendat judecarea cauzei și a adresat Curții Europene de Justiție patru întrebări, ${ }^{22}$ pe care Curtea le-a reformulat ${ }^{23}$ în felul următor: 1 . „reprezintă un act de comunicare publică, în sensul [art. 3 alin. (1) din directiva Infosoc], furnizarea, pe un site internet, de linkuri care pot fi accesate către opere protejate disponibile pe un alt site internet, în condițiile în care pe celălalt site operele în cauză sunt în liber acces"24? 2. art. 3 alin. (1) din directivă „se opune ca un stat membru să poată conferi o protecție mai amplă titularilor de drepturi de autor prevăzând că noțiunea de comunicare publică include mai multe operațiuni decât cele vizate la dispoziția menționată"25?

În mod surprinzător și regretabil, Curtea a adoptat hotărârea Svensson fără a solicita concluziile scrise ale avocatului general. Surprinzător, întrucât Svensson a fost prima cauză în care Curtea a fost nevoită să se pronunțe cu privire la interpretarea noțiunii de comunicare publică în domeniul digital, raportat la art. 3 alin. (1) din directiva Infosoc, și regretabil, întrucât, după cum vom vedea, Curtea a confirmat vechea teorie a „noului public”, care a fost respinsă de OMPI încă din anul 1948, cu ocazia Conferinței de modificare a Convenției de la Berna la Bruxelles. ${ }^{26}$

Curții i-au fost adresate două opinii ajutătoare de către două organizații internaționale specializate în domeniul drepturilor de autor. Prima opinie provine de la Societatea 
Europeană a Drepturilor de Autor ${ }^{27}$. Potrivit acesteia, în urma analizării celor trei elemente constitutive ale dreptului la comunicare publică, respectiv „opera”, „actul de comunicare” și comunicarea către un „public”, furnizarea de linkuri nu întrunește condițiile actului de comunicare publică. în primul rând, potrivit autorilor, în lipsa unei transmiteri a operei, aceasta fiind o condiție sine qua non a actului de comunicare publică, nu se realizează actul de comunicare publică ${ }^{28}$. lar prin postarea unui link, furnizorul linkului pune la dispoziția publicului doar adresa operei, dar nu opera în sine, astfel că nu se efectuează o transmitere a operei. ${ }^{29}$ Prin urmare, linkul joacă rolul unei forme neobișnuite de citare, asemenea unei note de subsol. ${ }^{30}$ în al doilea rând, chiar dacă, Curtea ar califica linking-ul drept un act de comunicare, lipsește cel de-al treilea element constitutiv al dreptului patrimonial la comunicare publică, respectiv elementul de „public”. ${ }^{31}$ Autorii opiniei invocă concluziile hotărârii $S G A E^{32}$, în cadrul căreia Curtea a pronunțat pentru prima oară că transmiterea operei, pentru fi considerată un act de comunicare publică, trebuie să se facă unui public diferit de cel către care a fost direcționat actul original de comunicare a operei, adică unui "nou public". 33

Cea de-a doua opinie provine de la Asociația Internațională Literară și Artistică (în continuare:ALAI) ${ }^{34}$ în forma unui raport. Potrivit acestuia, actul de punere la dispoziția publicului, ca și modalitate a comunicării publice, are trei condiții, anume să fie efectuat de o persoană fizică, să se adreseze în mod direct sau indirect publicului și să privească opere protejate prin dreptul de autor sau drepturi conexe. ${ }^{35}$ în ceea ce privește caracteristicile punerii la dispoziția publicului prin postarea pe internet a unor hiperlinkuri, autorii opiniei fac două precizări suplimentare: actul de punere la dispoziția publicului permite publicului să acceseze opere protejate prin dreptul de autor, dar actul nu include acele linkuri, care fac doar referire la sursa unde opera poate fi accesată. ${ }^{36}$ În lipsa unor explicații mai detaliate, presupunem că autorii sugerează că simpla postare a unui hiperlink, care arată locația operei protejate nu întrunește condițiile actului de punere la dispoziția publicului, pe când, de pildă, încorporarea unui videoclip pe pagina principală a rețelei de socializare facebook, care pornește fără intervenția suplimentară a utilizatorului constituie un asemenea act. ${ }^{37}$ Autorii mai precizează că este irelevant dacă conținutul pus la dispoziția publicului prin linkul în cauză a fost încărcat pe internet în mod legal sau fără consimțământul titularului de drepturi, deoarece actul de oferire în sine este cel care declanșează actul de comunicare publică. ${ }^{38} \mathrm{Nu}$ în ultimul rând, raportul-opinie insistă asupra noțiunii de public, delimitând publicul de cercul restrâns al familiei sau al prietenilor. Cu ocazia acestei argumentări și acești autori fac referire la teoria "noului public" introdusă de CJE și într-un mod subtil - dar fără succes - încearcă să reinterpreteze această teorie eronată bazându-se pe limbajul folosit de Curte în hotărârile sale ulterioare în așa fel, încât varianta reformulată să corespundă unei interpretări conforme cu tratatele administrate de OMPI.

În hotărârea din 13 februarie 2014, Curtea de Justiție a Uniunii Europene a scindat noțiunea de comunicare publică în două elemente constitutive, anume „actul de comunicare” și comunicarea „publică”. În ceea ce privește existența unui „,act de comunicare”, Curtea a constatat, făcând referire la jurisprudența sa anterioară, că „acesta trebuie înțeles în sens larg 
în scopul garantării, astfel cum rezultă în special din considerentele (4) și (9) ale Directivei 2001/29, a unui grad ridicat de protecție titularilor de drepturi de autor." ${ }^{39}$ Astfel, în concordanță cu raportul-opinie furnizat de ALAl, a hotărât că furnizarea, pe un site internet, a unor linkuri îndeplinește condiția unui „act de comunicare”, fiind suficient ca opera să fie pusă la dispoziția publicului, astfel încât persoanele care îl compun să poată avea acces la aceasta, chiar dacă ele nu se utilizează de această posibilitate. ${ }^{40}$

În ceea ce privește însă cel de-al doilea element, anume ca opera să fie comunicată „public", a constatat, în concordanță cu opinia Societății Europene de Drepturile de Autor următoarele: „atunci când totalitatea utilizatorilor unui alt site cărora operele în cauză le-au fost comunicate prin intermediul unui link care poate fi accesat puteau să acceadă în mod direct la operele respective pe site-ul pe care au fost comunicate inițial, fără intervenția administratorului celuilalt site, utilizatorii site-ului administrat de acesta din urmă trebuie să fie considerați destinatari potențiali ai comunicării inițiale și, așadar, ca făcând parte din publicul luat în considerare de titularii drepturilor de autor atunci când au autorizat comunicarea inițială. În consecință, în lipsa unui public nou, autorizarea titularilor de drepturi de autor nu se impune în cazul unei comunicări publice precum cea din litigiul principal." ${ }^{\prime 41}$ Or, titularul dreptului de autor, care postează pe internet opera protejată fără să restricționeze accesul publicului prin instalarea unor măsuri restrictive, precum accesul pe bază de logare, plata unor redevențe sau geo-blocking, pierde dreptul de a autoriza o nouă postare de către o altă persoană, fiindcă se prezumă că titularul a comunicat opera întregii populații internautice prin postarea inițială. lar potrivit jurisprudenței Curții, în lipsa unui public nou este imposibilă realizarea unui nou act de comunicare publică prin aceeași metodă tehnică. În hotărârea Svensson Curtea a preluat două teorii de interpretare a comunicării publice, respectiv teoria "noului public" și teoria "condițiilor tehnice specifice" și a mai consacrat o nouă teorie, anume cea a "măsurilor restrictive".

În privința ultimei întrebări, Curtea a statuat, că un stat membru nu poate conferi o protecție mai amplă titularilor de drepturi de autor prevăzând că noțiunea de comunicare publică include mai multe operațiuni decât cele vizate la această dispoziție. ${ }^{42}$

Înainte de a analiza repercusiunile hotărârii Svensson și evoluția subsecventă a noțiunii actului de comunicare publică în forma postării de hiperlinkuri, vom prezenta originea și inconvenientele celor trei teorii menționate, pe marginea jurisprudenței Curții de la Luxembourg.

\section{restrictive" \\ 4. Teoria „noului public, teoria „condițiilor tehnice specifice”și teoria „măsurilor}

a) SGAE: teoria "noului public"

Cauza SGAE este considerată hotărârea prin care Curtea Europeană de Justiție a introdus în dreptul de autor teoria "noului public"43. În litigiul principal din această cauză, cunoscută și sub denumirea Rafael Hoteles ${ }^{44}$, Sociedad general de Autores y Editores de España, organismul de gestiune colectivă a drepturilor de autor în Spania, a dat în judecată 
lanțul hotelier Rafael Hoteles S.A., susținând că acesta, prin amplasarea televizoarelor în camerele hotelului și difuzarea de muzică ambientală, a comunicat public opere aparținând repertoriului administrat de SGAE, fără să obțină autorizarea acestuia. Din acest motiv hotelul a încălcat drepturile de autor atașate operelor radiodifuzate. Proprietarul hotelului s-a apărat afirmând, că numărul mic al spectatorilor dintr-o cameră, care de obicei nu excede numărul membrilor de familie, nu întrunește cerința de public, lipsind astfel unul dintre elementele constitutive ale actului de comunicare publică. În faza apelului, Audiencia Provincial de Barcelona a suspendat judecarea cauzei și a întrebat Curtea Europeană de Justiție dacă distribuirea de semnal prin televizoarele clienților în camerele de hotel poate fi considerată act de comunicare publică în sensul art. 3 alin. (1) din directiva Infosoc? ${ }^{45}$

În analiza sa, Curtea a observat că directiva Infosoc nu definește noțiunea de comunicare publică. Totodată, potrivit considerentelor directivei, interpretarea drepturilor de autor prevăzute de directivă trebuie să fie suficient de largă pentru a permite asigurarea unui nivel ridicat de protecție a acestor drepturi ${ }^{46}$ și trebuie să fie în concordanță cu dreptul internațional. ${ }^{47}$ În ceea ce privește cea de-a doua condiție, Curtea a recurs la consultarea prevederilor articolului 11 bis al Convenției de la Berna ${ }^{48}$ și a interpretărilor aferente din Ghidul Convenției, elaborat de $\mathrm{OMP}^{49}$ în 1978. Astfel, preluând explicația din Ghid, Curtea a stabilit, că atunci „când autorul autorizează radiodifuzarea operei sale, el ia în considerare numai utilizatorii direcți, respectiv proprietarii echipamentelor de recepție, care personal sau în cercul lor privat de familie, recepționează programul. Dacă însă recepția programului vizează un public mai larg, eventual pentru profit, o nouă secțiune a publicului aude sau vede opera și comunicarea programului prin difuzor sau alt instrument analogic, nu mai corespunde unei recepții simple a programului, ci este un act independent prin care opera radiodifuzată este comunicată unui nou public (s.n.). ${ }^{150}$ Clientela hotelului formează un astfel de public nou. lar hotelul este organizația, care intervine în deplină cunoștință de cauză, în vederea asigurării clientelei sale acces la opera protejată. Fără intervenția hotelului, clienții săi, deși prezenți în acea zonă, nu ar fi avut posibilitatea să audă sau să vizioneze programul în cauză. ${ }^{51}$

Deși Curtea a ajuns la o decizie echitabilă și corectă, considerăm că argumentarea Curții este cât se poate de eronată. Posibilele surse ale failibilității argumentării sunt eroarea logică comisă de Curte în forma unui argument non sequitur în paragraful 40 și interpretarea greșită a prevederilor unui document internațional fără valoare legală. Astfel, în ceea ce privește argumentul non sequitur, nu există raport de cauzalitate între concluzia formulată de Curte în cea de-a doua propoziție din paragraful 40 al hotărârii și premisa formulată în prima propoziție al aceluiași paragraf. ${ }^{52}$ Or, Curtea susține, că "o comunicare făcută în circumstanțele asemănătoare celor din litigiul principal constituie, potrivit art. 11bis(1)(ii) din Convenția de la Berna, o comunicare făcută de o organizație radiodifuzoare diferită de organizația originală (s.n). Prin urmare (s.n.), o astfel de transmitere este făcută unui public diferit de cea către care a fost îndreptată actul original de comunicare a operei, adică unui nou public."(s.n.). În consecință considerăm că, Curtea confundă noțiunea de „noua comunicare publică” cu „comunicarea unui nou public". ${ }^{53}$

În al doilea rând, textul legal invocat de Curte, respectiv art. 11bis alin. (1)(ii) al Convenției este formulat cât se poate de clar, stabilind că autorul beneficiază de dreptul 
exclusiv de a autoriza „orice comunicare publică [..] când această comunicare este făcută printr-un alt organism decât cel de origine (s.n.)", formulare care, în nici un caz, nu susține interpretarea potrivit căreia autorul va autoriza comunicarea către un alt public. ${ }^{54}$ Curtea însă nu a procedat la interpretarea textului legal general obligatoriu invocat, ci, contrar dispozițiilor Convenției de la Viena cu privire la dreptul tratatelor ${ }^{55}$, a preluat explicațiile din documentul fără valoare legală, anume Ghidul OMPI din 1978. Mai mult de atât, în opinia lui Ficsor, întrucât Curtea nu a indicat expres paragrafele consultate din Ghid, putem doar intui că s-a referit în mod greșit la paragraful 11bis.12 din Ghid, care se referă de fapt la art. 11bis(1)(iii) din Convenție..$^{56}$ Totodată, autorii Ghidului au avut ca și scop elaborarea unui document asemănător unui manual pentru a asista implementarea și aplicarea prevederilor Convenției de către acele țări membre aflate în curs de dezvoltare, care nu aveau încă o tradiție a dreptului de proprietate intelectuală. ${ }^{57}$ Ghidul nu aspiră la a fi un document soft law cu valoare interpretativă, cu toate că este un document orientator de folos. Și nu în ultimul rând, Ghidul incipient din 1978 a fost înlocuit cu Ghidul din 2003, o lucrare realizată în urma analizelor minuțioase ale diferitelor probleme apărute în cursul aplicării Convenției, reflectând poziția actuală a OMPI. ${ }^{58}$ Este însă imposibil de imaginat, formulează galant Ficsor, că dacă, Curtea ar fi fost informată despre existența acestui nou ghid, să fi recurs la explicațiile ghidului învechit. ${ }^{59}$

Aceste opinii ale autorului renumit sunt susținute și de alți autori consacrați. ${ }^{60}$ Astfel, într-un articol întitulat Comunicare publică? Trei motive pentru care dreptul de autor se descurcă și fără „un nou” public, autorii relatează că această teorie a noului public a fost abandonată încă din anul 1948, cu ocazia Conferinței de revizuire a Convenției de la Berna din Bruxelles. Propunerea Belgiei de a interpreta noul act de comunicare publică prin retransmiterea operei radiodifuzate sub condiția procurării unui nou cerc de ascultători, a stârnit reacții negative în majoritatea delegaților țărilor membre. ${ }^{61}$ Principalul contraargument levita în jurul impracticabilității acestei condiții, în sensul că ar fi aproape imposibil de a decela între publicul "nou” și „cel original”. În consecință, cu contribuția altor trei țări membre, Belgia a formulat o nouă propunere, înlocuind criteriul „noului public" cu cel al "organizației diferite de cea originală", ceea ce presupune un nou act de comunicare de către o altă organizație decât cea care a radiodifuzat original opera. În final această variantă de propunere a fost adoptată de Conferință și aplicată ulterior de diverse instanțe naționale. ${ }^{62}$

Critica teoriei "noului public” de către Curte nu este doar un moft al teoreticienilor dreptului de autor, întrucât aceasta poate conduce la urmări grave în practică, precum introducerea unor formalități în protecția dreptului de autor sau epuizarea dreptului la comunicare publică, în ciuda prevederilor contrare ale Directivei Infosoc și contrar politicii internaționale a dreptului de autor.

\section{b) TVCathup: teoria "condițiilor tehnice specifice"}

Curtea de la Luxembourg a invocat în mai multe cauze teoria noului public ${ }^{63}$, cu toate că la scurt timp după adoptarea hotărârii SGAE, s-a evidențiat deficiența teoriei. Astfel, în cauza TVCatchup ${ }^{64}$ reclamantele din litigiul principal, organisme comerciale de 
radiodifuziune televizată, dețineau la momentul litigiului, drepturi de autor cu privire la emisiunile de televiziune, precum și cu privire la filmele și la celelalte elemente care erau incluse în emisiunile lor. Pârâtul TVCatchup furniza prin internet servicii de difuzare a unor emisiuni televizate, care permiteau utilizatorilor să recepționeze „în direct” prin internet fluxuri de emisiuni televizate gratuite, inclusiv emisiuni difuzate de reclamantele din litigiul principal. Specificitatea activității TVC era că permitea prin metode tehnice utilizatorilor serviciilor sale, să obțină acces doar la acele emisiuni, pe care le puteau viziona deja în mod legal pe baza abonamentului lor TV și doar dacă consimțeau la restricționarea utilizării serviciilor oferite de TVC pe teritoriul Regatului Unit. Site-ul TVC dispunea de echipamente care îi permiteau șă identifice locul în care se afla utilizatorul și să refuze accesul atunci când condițiile impuse nu erau îndeplinite. ${ }^{65}$ Altfel spus, publicul care avea acces la serviciile TVC era același public, căruia îi fusese deja comunicat conținutul protejat prin radiodifuzare de către organismele comerciale de radiodifuziune televizată. În aceste condiții, High Court of Justice (England \& Wales), Chancery Division, a suspendat judecarea cauzei și a adresat Curții o serie de întrebări, prin intermediul cărora, solicita, în esență, detalierea modului de interpretare a art. 3 al Directivei Infosoc în oglinda teoriei „noului public”. ${ }^{66}$

Curtea s-a pronunțat fără să solicite concluziile Avocatului general. În primul rând, a respins apărarea TVC, prin care acesta argumenta că, comunicarea conținutului protejat prin tehnica „live-streaming” nu întrunește condițiile actului de comunicare publică, întrucât nu a fost îndeplinită cunoscuta condiție a „noului public" 67 și a susținut că „situațiile examinate în cauzele în care s-au pronunțat hotărârile menționate diferă în mod clar de situația în discuție în prezenta cauză." ${ }^{68}$ (sic!). Astfel, Curtea a menținut în continuare teoria noului public și a lărgit interpretarea actului de comunicare publică prin introducerea teoriei „condițiilor tehnice specifice”. Or, în viziunea Curții, în situații precum cele din litigiul principal, „fiecare dintre [cele] două transmisii trebuie să fie autorizată în mod individual și separat de autorii în cauză, dat fiind că fiecare dintre ele este efectuată în condiții tehnice specifice (s.n.), potrivit unui mod diferit de transmisie a operelor protejate și că fiecare dintre ele este destinată unui public." lar în aceste situații nu este necesară examinarea condiției noului public. ${ }^{69}$

Și această motivare a Curții a fost criticată de literatura de specialitate ${ }^{70}$, printre altele, pentru inconsecvența și incompatibilitatea sa cu tratatele internaționale. Astfel, din TVcatchup s-ar putea deduce că retransmisiile din hotărârile anterioare ale Curții, precum SGAE și Premier League $^{71} \mathrm{nu}$ au fost efectuate în condiții tehnice speciale, utilizând metode diferite de transmitere. De fapt, în SGAE prima transmisie a fost una terestră primită de către antena principală a hotelului, în timp ce retransmisia semnalului a fost făcută prin intermediul unei rețele de cablu hotelier. Iar în Premier League prima transmisie a fost efectuată prin satelit, pe când a doua a avut loc pe ecranele televizoarelor aflate într-un bar public ${ }^{72}$.

Totodată, art. 11bis(1) din Convenția de la Berna nu limitează dreptul exclusiv al autorului la cazuri în care retransmiterea a fost făcută în condiții tehnice specifice și întrucât prin hotărârea Curții drepturile minime asigurate de Convenție nu sunt extinse, ci dimpotrivă, sunt supuse unor condiții suplimentare, considerăm că hotărârea Curții este in conflict cu prevederile Convenției ${ }^{73}$ și în mod indirect, și cu prevederile directivei însăși. 


\section{c) Svensson: teoria „măsurilor restrictive” și critica hotărârii Curții}

„Problema cu hiperlinkurile este că oricare dintre rezultate poate avea implicații negative. Dacă fiecare hiperlink, care duce la o operă protejată ar reprezenta o comunicare publică supusă autorizării prealabile a titularului de drepturi, acesta ar avea în mod evident consecințe dezastruoase asupra funcționării rețelei de web. Pe de altă parte, dacă [postarea de] hiperlinkuri nu ar constitui în nici un caz un act de încălcare al drepturilor de autor, obiectivul directivei InfoSoc de a oferi un nivel ridicat de protecție pentru autori ar putea fi compromis." ${ }^{\prime 74}$ Prinsă în această dilemă, Curtea de la Luxembourg a încercat prin hotărârea Svensson să găsească o cale de mijloc, prin care să asigure o protecție ridicată drepturilor de autor, pe de o parte, și să salveze internetul, pe de altă parte. Din păcate însă, prin menținerea teoriei "noului public” și transpunerea acesteia în domeniul online, Curtea a provocat mai multe deziderate decât avantaje.

Astfel, după cum am arătat mai sus, teoria „noului public", teoria "condițiilor tehnice specifice”, precum și teoria „măsurilor restrictive” sunt incompatibile cu tratatele internaționale, în special Convenția de la Berna și WTC, deoarece fiecare dintre cele trei teorii supune dreptul la comunicare publică unor condiții suplimentare față de prevederile tratatelor. Art. 11bis(i) al Convenției de la Berna stabilește ca și unică condiție a actului de retransmitere prin radiodifuzare, ca retransmiterea să fie efectuată de un organism diferit de cel care a făcut transmisia inițială, iar teoria unui "nou public” a fost abandonată în mod expres de către Conferința de la Bruxelles. Art. 8 din WCT, care este o completare a Convenției de la Berna, vorbește despre „orice comunicare publică”, fără a distinge între transmisii inițiale și retransmisii, indiferent de tehnologia utilizată. ${ }^{75}$ Pentru aceste motive, susținem și noi alături de specialiști renumiți în dreptul proprietății intelectuale, că nu există niciun temei legal pentru introducerea condițiilor suplimentare, precum existența unui nou public sau folosirea unor condiții tehnice specifice cu ocazia retransmiterii operei, după cum nu este necesară nici utilizarea unor măsuri restrictive pentru protecția dreptului la comunicare publică. ${ }^{76}$

Alte două efecte nefavorabile ale hotărârii Svensson, sunt riscul introducerii unor condiții formale pentru existența protecției și epuizarea parțială a dreptului de comunicare publică. Or, pentru ca dreptul de a autoriza comunicările subsecvente să existe, autorul trebuie să recurgă la formalități, anume să instaleze măsuri restrictive, contrar prevederilor art. 5(2) din Convenția de la Berna, și în cauza de față, și celor din art. 8 din WCT. ${ }^{77}$ lar în ceea ce privește epuizarea dreptului, un autor care își publică opera pe un website fără măsuri restrictive, își pierde dreptul de a controla comunicările ulterioare prin această modalitate, cu toate că considerentele (29) și art. 3 alin. (3) din directiva Infosoc, în concordanță cu tratatele internaționale, prevăd expres că epuizarea afectează exclusiv dreptul de distribuție, nu și dreptul de comunicare publică. Principiul care stă la baza introducerii în dreptul internațional a ideii de epuizare a dreptului de distribuție este acela de a împiedica titularul de drepturi să exploateze o lucrare după ce a realizat valoarea economică completă a operei prin punerea ei pe piață. În caz contrar, ar împiedica funcționarea optimă a pieței. ${ }^{78}$ Aceeași explicație nu se pretează însă și la dreptul la comunicare publică, din moment ce exploatarea repetată a operei este de însăși esența acestui drept. Nu în ultimul rând, pentru motivele sus-menționate teoria „noului public” favorizează nejustificat utilizatorii operei în dauna titularilor de drepturi. ${ }^{79}$ 
În următorul capitol vom prezenta două cauze subsecvente legate de activitatea de linking și străduința Curții în restabilirea echilibrului între drepturile de autor și utilizarea liberă a internetului.

\section{Jurisprudența corectivă a Curții în BestWater și GS Media}

În cauza BestWater, un videoclip promoțional realizat de o firmă germană specializată în comercializarea de sisteme de filtrare a apei, reclamanta din litigiul principal a fost încărcat pe YouTube fără autorizarea acesteia. MM. Mebes și Pötsch, doi agenți comerciali care acționau în numele unui concurent al reclamantei, au postat prin tehnica de ,încadrare” (framing) videoclipul YouTube pe website-urile lor, motiv pentru care BestWater i-a dat în judecată pentru încălcarea drepturilor ei de autor, solicitând încetarea difuzării și despăgubiri. ${ }^{80}$ Instanța națională, aplicând doctrina Svensson și având în vedere specificitatea postării conținutului protejat, a suspendat judecarea cauzei și a solicitat Curții să stabilească dacă încadrarea (framing) sau încorporarea (embedding) pe un website a unui conținut protejat, publicat pe un alt website, constituie un act de comunicare publică în înțelesul directivei Infosoc, chiar dacă noua postare nu întrunește nici condițiile unui nou public și nici condițiile tehnice specifice ${ }^{81}$ Curtea, invocând prevederile art. 99 din Regulamentul de procedură, ${ }^{82}$ a asimilat situația de fapt cazurilor anterior judecate și a emis o ordonanță motivată. A stabilit că, având în vedere, că postarea conținutului protejat s-a realizat prin aceleași mijloace tehnice ca și comunicarea inițială a operei, respectiv opera nu a fost pusă la dispoziția unui nou public, postarea hiperlinkului nu este considerată un act de comunicare publică potrivit art. 3 alin. (1) din directiva Infosoc și prin urmare, nu este necesară nici autorizarea titularilor de drept. ${ }^{83}$ Astfel, Curtea a confirmat că linkurile încadrate (tehnica framing) sau încorporate (tehnica embedding) nu sunt tratate diferit de hiperlinkurile simple sau profunde (deep links), deși o diferențiere între hiperlinkurile simple, care arată doar locația, unde se regăsește opera protejată, și toate celelalte modalități de linking, astfel cum schițează autorii raportului ALAl, ar fi fost binevenită. Tindem să fim de acord cu opinia autorilor raportului, potrivit căreia, linkurile simple, care direcționează utilizatorul către pagina principală a website-ului, nu ar trebui să constituie un act de comunicare publică, deoarece asemenea notelor de subsol, acestea identifică doar locul în care se află opera, pe când toate celelalte modalități de linking pun la dispoziția publicului opera însăși. ${ }^{84}$

Constatăm totodată cu regret că, Curtea nu a luat în considerare faptul că videoclipul a fost încărcat pe YouTube fără autorizarea titularei de drept și ne întrebăm dacă în oglinda acestui detaliu a fost justificată asimilarea acestui litigiu cauzelor judecate de Curte și pronunțarea unei ordonanțe motivate, în loc de hotărâre. Ne-am întrebat totodată, dacă putem concluziona că punerea la dispoziția publicului a unei opere protejate prin postarea unui link nu constituie act de comunicare publică în sensul art. 3 alin. (1) din Directiva Infosoc, indiferent dacă publicarea inițială a operei a fost făcută cu sau fără autorizarea titularului de drepturi, în situația în care nu există un nou public.

Curiozitatea ne-a fost satisfăcută în privința ultimei întrebări prin hotărârea GS Media pronunțată de Curte în 2016. Această cauză a fost o nouă șansă pentru Curte să 
renunțe la teoria „noului public” și să se alinieze la exigențele dreptului internațional de autor. Din păcate însă, Curtea nici de această dată nu s-a lepădat de mult criticata doctrină, deși, asemănător cauzei TVCatchup, și în GS Media a s-a văzut nevoit să lărgească sfera acelor acte, care constituie comunicare publică și în lipsa unui nou public.

În octombrie 2011, GeenStijl.nl, unul dintre cele mai vizitate tabloide din Olanda, operat de GS Media a publicat un hiperlink care îndrepta cititorii către un site de stocare de date australian, denumit Filefactory.com, de unde utilizatorii puteau descărca gratuit fotografii, care urmau să fie publicate în revista Playboy abia în luna decembrie. În pofida somațiilor societății Sanoma, GS Media a refuzat să șteargă hiperlinkul în discuție. În final, hiperlinkul a fost neutralizat prin îndepărtarea fotografiilor de pe site-ul de origine. Întreaga operațiune a fost repetată de mai multe ori, deoarece GS Media a continuat să publice hiperlinkuri, care direcționau utilizatorii către diferite site-uri, care publicaseră fotografiile în cauză fără autorizarea Sanoma. Sanoma a introdus o acțiune împotriva GS Media pentru încălcarea drepturilor ei de autor. În cadrul recursului, Hoge Raad de Nederlanden a observat că, deși fotografiile în cauză nu erau de negăsit pe internet înainte ca GS Media să posteze hiperlinkul pe site-ul GeenStijl, dine moment ce Filefactory nu era un site cunoscut, GS Media a facilitat foarte mult accesul la fotografii, lărgind mult cercul acelor persoane, care aveau cunoștință de existența fotografiilor.

În aceste condiții, instanța națională a adresat, prin procedura trimiterii preliminare, o serie de întrebări Curții, ${ }^{85}$ care ridicau de fapt patru probleme, respectiv, relevanța faptului că operele în discuție nu au fost încă publicate în vreun alt mod cu autorizația titularului, a împrejurării că titularul de drepturi nu a autorizat publicarea operelor în cauză pe acest din urmă site, a faptului că furnizarea hiperlinkurilor facilitează mult găsirea operelor în discuție, precum și a faptului că cel care postează respectivele linkuri cunoștea sau trebuia să cunoască această situație de fapt. ${ }^{86}$

Curtea, după reluarea și menținerea argumentelor consacrate în jurisprudența sa anterioară - anume, cele privitoare la structura actului de comunicare publică, necesitatea interpretării largi a dreptului, cu luarea în considerare a teoriei noului public, ${ }^{87}$ a lipsei măsurilor tehnice restrictive ${ }^{88}$ și a modalităților tehnice specifice ${ }^{89}$ - introduce două elemente noi. Acestea sunt buna credință a celui care a postat linkul și caracterul lucrativ al postării linkului.

În ceea ce privește buna-credință a celui care a postat linkul, Curtea a subliniat „rolul indispensabil al utilizatorului și caracterul deliberat al intervenției sale" ${ }^{\circ 0}$, atribuind un caracter constitutiv intențiilor sale. Or, postarea unui hiperlink constituie un act de comunicare publică, în cazul în care o persoană știe sau ar fi trebuit să știe că hiperlinkul în cauză oferă acces la o operă pusă la dispoziția publicului fără autorizarea titularului de drepturi, respectiv postarea nu constituie o asemenea comunicare dacă utilizatorul este de bună-credință. ${ }^{91}$ În aceeași ordine de idei, persoana, care evită măsurile restrictive, se prezumă a fi de rea-credință și postarea de către aceasta se consideră a fi o intervenție deliberată fără de care utilizatorii nu ar fi putut beneficia de operele difuzate. Curtea a motivat această soluție prin importanța aparte a internetului pentru libertatea de exprimare și de informare, precum și dificultățile cu care s-ar confrunta utilizatorii cu ocazia verificării dacă site-ul internet către care se presupune că, conduc linkurile postate, conferă acces la opere 
protejate și dacă titularii drepturilor de autor ai acestor opere au autorizat publicarea lor pe internet. ${ }^{92}$ Considerăm, alături de alți autori că, cunoașterea de către utilizator al ilegalității primei comunicări nu constituie un element al actului prejudiciabil, ${ }^{93}$ cunoașterea caracterului ilegal al postării poate fi cel mult, un element al răspunderii celui care se face vinovat de comiterea prejudiciului. Dar nici această soluție nu este acceptabilă din perspectiva dreptului de autor, după cum vom argumenta în continuare.

În al doilea rând, potrivit Curții, persoanele care postează linkuri în scop lucrativ ori în scopul obținerii unui profit, sunt obligați să efectueze verificările necesare pentru a se asigura că opera vizată nu este publicată nelegal pe site-ul la care conduc respectivele hiperlinkuri, și se prezumă relativ că această postare a intervenit cunoscându-se pe deplin natura protejată a operei și lipsa unei autorizații de publicare din partea titularului dreptului de autor. ${ }^{94}$

Hotărârea GS Media a provocat reacții ambivalente. Pe de o parte, Curtea a nuanțat, în sfârșit, actul de comunicare publică în cazul în care conținutul protejat a fost postat fără consimțământul titularului de drept ${ }^{95}$. Pe de altă parte însă, în aroganța sa, susține Targosz, Curtea a ignorat zeci (chiar sute) de ani de teorie a dreptului de autor, și în ciuda tuturor criticilor din literatura de specialitate și a concluziilor avocatului general, a oferit o combinație de concepte incoerente. ${ }^{96}$ Curtea, cu o încăpățânare de neînțeles, a păstrat teoria „noului public". Pentru a putea fi menținută, Curtea a adoptat soluții punctuale, care au rezolvat temporar problemele generate de această teorie inadecvată. De această dată, soluția a fost condiția cunoașterii caracterului ilegal al primei comunicări. Acest criteriu are ca și efect, crearea unei incertitudini legale, întrucât „utilizatorii de internet nu știu și nu dispun de mijloace pentru a verifica dacă comunicarea publică inițială a unei opere protejate, care poate fi accesată în mod liber pe internet, a fost efectuată cu sau fără consimțământul titularului dreptului de autor." 97 Pe de altă parte, Curtea a modificat caracterul obiectiv al răspunderii pentru încălcarea dreptului la comunicare publică într-o răspundere subiectivă, dependentă de cunoașterea ilegalității postării inițiale de către prejudiciatorul subsecvent.

În ceea ce privește criteriul caracterului lucrativ al postării, se consideră justificat tratamentul mai sever al acelui utilizator, care pune la dispoziția publicului opere protejate în scopul de a obține profit pe seama eforturilor depuse de titularul de drepturi, atât timp, cât caracterul lucrativ al postării nu constituie un element al actului de comunicare publică sau o condiție sine qua non a răspunderii pentru încălcarea dreptului la comunicare publică. ${ }^{98}$ Or, în cauza Del Corso, ${ }^{99}$ Curtea în mod eronat a ajuns la concluzia, că difuzarea de fonograme de către un medic stomatolog în prezența pacienților, ca muzică ambientală, nu constituie act de comunicare publică, deoarece nu conduce la o creștere a clientelei sale și nici la creșterea prețului serviciilor prestate, motiv pentru care o astfel de difuzare nu are caracter lucrativ. ${ }^{100}$ Ulterior, în hotărârea Reha Training ${ }^{101}$, printr-o formulare iscusită, Curtea a modificat jurisprudența Del Corso, susținând că, caracterul lucrativ al difuzării de emisiuni televizate de operatorul unui centru de refacere în spațiile sale este „de natură a fi luat în discuție la stabilirea cuantumului remunerației datorate, ${ }^{102}$ nefiind deci un element al răspunderii.

Observăm însă, cu regret, că în cadrul analizei importanței caracterului lucrativ al postării de hiperlinkuri, Curtea nu invocă concluziile din Reha Training, ci se referă la hotărârea Del Corso. Cu toate acestea, suntem de acord și cu susținerea lui Ficsor, potrivit căreia din 
fericire, în GS Media, Curtea nu face nicio declarație, care ar contraveni jurisprudenței corectate în Reha Training. ${ }^{103}$

Concluzionând, suntem de părere că, soluția Curții este compatibilă cu dreptul internațional și prevederile directivei Infosoc, cu condiția ca, caracterul lucrativ al activității utilizatorului să nu constituie un element al actului de comunicare publică și nici o condiție a răspunderii celui care furnizează linkul, ci doar un simplu aspect de natură a fi luat în considerare la stabilirea cuantumului remunerației datorate. Din contră, în cazul în care caracterul comercial al activității se consideră a fi un element sau o condiție precum cele menționate, ne aflăm în prezența multiplicării condițiilor prevăzute de tratatele internaționale și directiva Infosoc cu privire protecția dreptului la comunicare publică. În consecință, acest din urmă caz, dispozițiile imperative privind asigurarea protecției minime a drepturilor de autor ar fi încălcate.

\section{Concluzii}

Curtea a adoptat în hotărârea SGAE teoria "noului public" ca și criteriu de interpretare a dreptului la comunicare publică a creațiilor intelectuale, prevăzut de art. 3 alin. (1) directivei Infosoc, în concordanță cu tratatele internaționale administrate de OMPI. Curtea a păstrat această teorie până în prezent, în pofida incompatibilității sale cu prevederile imperative ale tratatelor ratificate de UE și de statele sale membre, în ciuda ineficienței sale, dovedită la scurt timp după consacrare și cu toate că ea a fost abandonată de specialiștii dreptului de autor încă din anul 1948. Mai târziu, în TVCathup, Curtea a încercat să corecteze criteriul "noului public” prin substituirea ei parțială cu teoria „condițiilor tehnice specifice”, care, asemănător primei teorii, rezolvă într-un mod judicios anumite probleme punctuale, însă nu este în măsură să ofere o soluție generală în ceea ce privește dreptul la comunicare publică în mediul digital. În cauza Svensson, prima cauză ce presupunea interpretarea dispozițiilor directivei Infosoc referitoare la comunicarea publică a operelor de creație intelectuală prin postarea unor hiperlinkuri, Curtea, în dorința de a salva libertatea internetului pe marginea protecției drepturilor de autor, a extins teoria "noului public” și la activitatea de linking, corectată de această dată prin teoria „măsurilor restrictive”. Și această teorie este în conflict cu dreptul internațional și dispozițiile directivei Infosoc, motiv pentru care și această hotărâre a fost criticată, pe bună dreptate, de literatura de specialitate. Mai mult, hotărârea Svensson a cauzat și alte efecte nedorite, anume riscul introducerii formalităților ca șo condiției a protecției dreptului de autor și epuizarea parțială a dreptului la comunicare publică, înclinând balanța mult în favoarea utilizatorilor de internet. Cauza BestWater a întărit jurisprudența Curții și aparent a decis că în cazul furnizării unui link este indiferent dacă opera astfel comunicată inițial a fost pusă la dispoziția publicului cu sau fără autorizarea titularului de drepturi. Această aparență a fost însă combătută prin hotărârea GS Media, cauză în care Curtea a introdus totodată, criteriul bunei-credințe a furnizorului hiperlinkului și prezumția potrivit căreia acel utilizator, care postează hiperlinkuri în scopul obținerii unui profit, este dator să se asigure că linkul furnizat nu direcționează publicul către un conținut pus la dispoziția publicului fără autorizarea titularului de drept. 
Observăm că, Curtea a depus eforturi reale în găsirea unui echilibru între funcționarea liberă și optimă a internetului, și asigurarea unei protecții adecvate drepturilor de autor. Suntem în cunoștința deplină a dificultăților găsirii unei soluții adecvate. Această certitudine ne este susținută prin diversitatea de opinii ${ }^{104}$ și multitudinea de soluții propuse, ori aplicate de literatura de specialitate sau instanțele naționale, dintre care niciuna nu este general acceptată sau aplicabilă. Dintre aceste soluții putem aminti teoria licenței implicite, ${ }^{105}$ autorizarea expresă, licența colectivă, instrucțiunile încorporate pe website sau introducerea de noi excepții în directivă, ${ }^{106}$ sau teoria inexistenței actului de comunicare în lipsa transmiterii operei. ${ }^{107}$ Totodată, considerăm că este foarte puțin probabilă, dacă nu chiar imposibilă găsirea unei soluții generale și permanente, care să satisfacă cerințele dreptului de autor fără să sacrifice funcționarea optimă a internetului, mai ales, în lumina schimbărilor tehnologice constante și rapide.

Cu toate acestea, suntem de părere că, calea aleasă de Curte este una dintre cele mai nefericite din perspectiva actualei reglementări internaționale și implicit, a dreptului Uniunii Europene. Putem doar spera că în viitor literatura de specialitate dezvoltată de specialiștii dreptului de autor și evoluția soluțiilor propuse de aceștia vor oferi Curții un sprijin și o alternativă de reformare a jurisprudenței sale în așa fel, încât să restabilească echilibrul real între interesele diverselor categorii persoane, cu respectarea dreptului internațional privind drepturile de autor.

* Doctorand, Universitatea Eötvös Loránd, Facultatea de Drept, Departamentul de Drept Privat European și Dreptul European al Afacerilor, cadru didactic asociat al Universității Sapientia, Departamentul de Științe Juridice, consilier juridic; kis_reeka@yahoo.com.

${ }^{1}$ Gyula Fábián, Drept instituțional al Uniunii Europene, Editura Hamangiu, Sfera Juridică, București, 2012, p. 404

2 Pentru detalii a se vedea Péter Mezei, Enter the matrix: the effects of the CJEU's case law on linking and streaming technologies în Gewerblicher Rechtsschutz und Uheberrecht Internationaler Teil, octombrie 2016, p. 877-900, disponibil pe https://ssrn.com/abstract=2784926 (accesat la 23.06.2017., ora 18:14), p. 877 și urm.

${ }^{3}$ Sam C. Velze, Communication to a New Public? A Critical Analysis of the CJEU's 'New Public' Criterion in European Copyright Law, Thesis Research Master Information Law, https://www.ivir.nl/publicaties/download/1744.pdf (accesat la data de 23.06.2017., ora 19:20), p. 28

${ }^{4}$ Pentru protecția operelor literare şi artistice completată la Paris la 4 mai 1896, revizuită la Berlin la 13 noiembrie 1908, completată la Berna la 20 martie 1914, revizuită la Roma la 2 iunie 1928, revizuită la Bruxelles la 26 iunie 1948, revizuită la Stockholm la 14 iulie 1967 şi la Paris la 24 iulie 1971 şi modificată la 28 septembrie 1979

${ }^{5}$ P. Bernt Hugenholtz, Sam C. Van Velze, Communication to a New Public? Three Reasons Why EU Copyright Law Can Do Without a "New Public” în International International Review of Intellectual Property and Competition Law (2016) 47:797-816, p. 798

${ }^{6} /$ dem, p. 799

${ }^{7}$ Idem, p. 801

${ }^{8}$ a se vedea http://www.orda.ro/default.aspx?pagina=213 (accesat la 15 februarie 2017, ora 12:52)

${ }^{9}$ adoptate la Geneva la data de 20.12.1996. 
${ }^{10} \mathrm{~A}$ se vedea preambulul WCT.

11 iar în cazul WPPT, a performanțelor fixate.

12 L'Association Littéraire et Artistique Internationale -ALAI, Report and Opinion on the making available and communication to the public in the internet environment - focus on linking techniques on the Internet, 9 martie 2013, http://www.alai.org/en/assets/files/resolutions/making-available-right-report-opinion.pdf (accesat la 15 februarie 2017, ora 13:01), p.3

${ }^{13}$ Considerentele (15) ale directivei Infosoc

${ }^{14}$ Considerentele (31) ale directivei Infosoc

${ }^{15}$ Din formularea explicită "prin cablu sau fără cablu" reiese că directiva nu se aplică performanțelor off-line, acestea rămânând nearmonizate la nivelul UE. Pentru detalii a se vedea ALAI (n. 12), p. 5

${ }^{16}$ Aspecte ale Drepturilor de Proprietate Intelectuală legate de Comerț face parte din Acordul de înființare a Organizației Mondiale a Comerțului, semnat la Marrakesh în aprilie 1994

17 Decizia Consiliului din 16 martie 2000 de aprobare, în numele Comunității Europene, a Tratatului OMPI privind drepturile de autor și a Tratatului OMPI privind interpretările și execuțiile și fonogramele

${ }^{18}$ Hotărârea din 13 februarie 2014, Svensson și alții, C-466/12, EU:C:2014:76

19 Idem, pct. 8

${ }^{20}$ Idem, pct. 9

${ }^{21}$ Idem, pct. $10-11$

22 1) Fapta unei alte persoane decât titularul drepturilor de autor asupra unei opere de a furniza pe pagina sa de internet un link care poate fi accesat spre această operă constituie o comunicare publică a operei în sensul articolului 3 alineatul (1) din Directiva [2001/29]?

2) Examinarea primei întrebări este influențată de împrejurarea că opera la care trimite linkul se află pe o pagină de internet care poate fi accesată fără nicio restricție sau, dimpotrivă, că accesul la această pagină este restricționat într-un fel sau altul?

3) La examinarea primei întrebări, trebuie să se facă o distincție după cum opera, după accesarea linkului, este afișată pe o pagină de internet distinctă sau, dimpotrivă, creează impresia că este afișată pe aceeași pagină [de internet]?

4) Un stat membru poate oferi o protecție mai extinsă dreptului exclusiv al autorilor stabilind că noțiunea de comunicare publică include mai multe operațiuni decât cele care decurg din articolul 3 alineatul (1) din Directiva 2001/29?"

${ }^{23}$ Observăm cu părere de rău, că din varianta reformulată a întrebărilor, Curtea a omis a treia întrebare a instanței naționale, prin care aceasta întreba Curtea dacă trebuie să se facă o distincție cum opera, după accesarea linkului, este afișată pe o pagină de internet distinct (precum în cazul hiperlinkurilor simple sau interne) sau, dimpotrivă, creează impresia că este afișată pe aceeași pagină (precum în cazul linkingului realizat prin tehnica framing sau embedding)?

${ }^{24}$ Svensson, (n.18), pct. 14

${ }^{25}$ Idem, pct. 33

${ }^{26}$ A se vedea Hugenholtz și Velze (n. 5), p. 808

${ }^{27}$ European Copyright Society - ECS: Opinion on The Reference to the CJEU in Case C-466/12 Svensson, 15 februarie 2013, https://europeancopyrightsocietydotorg.files.wordpress.com/2015/12/europeancopyright-society-opinion-on-svensson-first-signatoriespaginatedv31.pdf (accesat la 16 februarie 2017, ora 9:15)

${ }^{28}$ Idem, par. 11, 26 și urm.

${ }^{29}$ Idem, p. 8 și urm. Autorii opiniei nu fac diferență între diversele moduri de folosire a linkurilor, precum linkuri simple, linkuri profunde, linkuri încadrate sau încorporate. În opinia noastră, primele două pot fi asemănate eventual unor adrese de trimitere, întrucât indică utilizatorului adresa la care se regăsește 
opera, însă nu putem fi de acord cu afirmația potrivit căreia tehnica de framing sau embedding se limitează la a fi doar o adresă de citare. De exemplu facă o persoană își verifică "news feed"-ul pe pagina de socializare facebook și mișcă cursorul deasupra videoclipurilor YouTube distribuite pe facebook, videoclipul va începe să ruleze mut, fără nicio altă intervenție a persoanei, mulțumită funcției de 'hover' dezvoltată de rețeaua de socializare.

${ }^{30}$ Autorii opiniei au susținut acest argument inclusiv prin recurgerea la exemple din hotărârile instanțelor naționale. A se vedea hotărârea Curții Federale Germane în cauza Paperboy, I ZR 259/00 (17 iulie 2003) [2005], hotărârea Curții Supreme din Norvegia în cauza Napster.no (2006) IIC 120 (26 ianuarie 2005) și hotărârea Curții de Apel în cauza Perfect 10 vs. Google, Inc., 416 F.Supp. 2 d 828 (C.D. Cal.2006), 487 F.3d 701 (USCA, 9th Cir. 2007)

${ }^{31} \mathrm{ECS},($ n.27), par. 46 și urm.

32 Hotărârea din data de 7 decembrie 2006, SGAE, C-306/05, EU:C:2006:764

${ }^{33}$ Idem, par. 40, ECS (n.27), par. 27

${ }^{34} \mathrm{ALAl}, 2013$ (n. 12)

${ }^{35}$ Idem, p. 1

${ }^{36}$ Idem, p.1

${ }^{37}$ Despre diferența dintre hiperlinkuri și linkuri inline a se vedea ALAl, 2013 (n.12), p. 8

${ }^{38}$ ALAI, 2013 (n.12), p. 1

${ }^{39}$ Svensson(n.18), pct. 17

40 Idem., pct. 19.

${ }^{41}$ Idem, pct. $27-28$

${ }^{42}$ Idem, pct. 37

${ }^{43}$ De fapt, Avocatul general La Pergola a fost cel care a dezvoltat pentru prima oară în cadrul concluziilor din data de 9 septembrie 1999, Egeda, C-293/98, EU:C:1999:403

${ }^{44}$ SGAE (n.32)

${ }^{45}$ Idem, pct. 32

${ }^{46}$ Idem, pct. 34-36

${ }^{47}$ Directiva Infosoc, considerentele (19)

${ }^{48}$ Art. 11 bis, astfel cum a fost ratificată prin LEGE nr. 77 din 8 aprilie 1998 pentru aderarea României la Convenţia de la Berna pentru protecţia operelor literare şi artistice din 9 septembrie 1886, în forma revizuită prin Actul de la Paris la 24 iulie 1971 şi modificată la 28 septembrie 1979:

(1) Autorii de opere literare şi artistice beneficiază de dreptul exclusiv de a autoriza: $1^{*}$ radiodifuzarea operelor lor sau comunicarea publică a acestor opere prin orice alt mijloc servind la difuzarea fără fir a semnalelor, a sunetelor sau a imaginilor; $2^{*}$ orice comunicare publică fie prin fir, fie fără fir a operei radiodifuzate, când aceasta comunicare este făcută printr-un alt organism decât cel de origine; $3^{*}$ comunicarea publică a operei radiodifuzate prin difuzor sau prin orice alt instrument asemănător, transmițător de semnale, de sunete sau de imagini.

(2) Revine legislațiilor ţărilor Uniunii să reglementeze condiţiile de exercitare a drepturilor la care se referă alin. (1) de mai sus, dar aceste condiţii nu vor avea decât un efect strict limitat la ţara care le va stabili. Ele nu vor putea în nici un caz sa aducă atingere dreptului moral al autorului, nici dreptului, care aparţine autorului, de a obţine o remunerare echitabila stabilită de către autoritatea competentă, în lipsa unui acord amiabil.

(3) În lipsa unei prevederi contrare, autorizaţia acordată, potrivit alin. (1), nu cuprinde şi autorizaţia de a înregistra opera radiodifuzată prin intermediul unor instrumente de fixare a sunetelor sau imaginilor. Se rezervă totuşi legislațiilor ţărilor Uniunii regimul înregistrărilor efemere, efectuate de un organism de 
radiodifuziune prin propriile sale mijloace şi pentru emisiunile sale. Aceste legislaţii vor putea autoriza păstrarea acestor înregistrări în arhive oficiale, datorită caracterului lor excepţional de documentare.

${ }^{49} \operatorname{SGAE}$ (n. 32), pct. 41

50 Ibidem

${ }^{51}$ Idem, pct. 42

52 Pentru detalii a se vedea Mihály J. Ficsor, Svensson: honest attempt at establishing due balance concerning the use of hyperlinks - spoiled by the erroneous "new public" theory, http://www.copyrightseesaw.net/archive/?sw_10_item=68 (accesat la 01,03,2017., ora 10:07), p. 4 și urm.

53 Idem., p. 5

${ }^{54}$ Ibidem.

55 Încheiată la Viena la 23 mai 1969, publicată în ediţia oficială a Monitorului Oficial „Tratate Internaţionale", volumul 4, pag. 53. A se vedea art. 32 din Tratatul de la Viena, care stabilește procedura de interpretare a textului Convenției, respectiv se poate recurge la mijloace complementare de interpretare, în cazul în care interpretarea dată conform articolului 31, anume o interpretare bazată pe analiza textului legal, lasă sensul ambiguu sau obscur sau duce la un rezultat vădit absurd sau neraţional. În același sens Ficsor (n.52), p. 10, Hugenholtz și Velze (n. 5), p. 808.

${ }^{56}$ Mai multe detalii cu privire la posibilele interpretări a se vedea Ficsor (n.52), p. 9

${ }^{57}$ Ficsor (n.52), p. 13 cu trimitere la Cuvântul înainte al Ghidului din 1978

${ }^{58}$ Idem, p. 3

59 Idem, p. 4

${ }^{60}$ Sam Ricketson, Jane Ginsburg, International Copyright and Neighboring Rights - The Berne Convention and Beyond, Oxford University Press, 2006, p. 734

${ }^{61}$ Hugenholtz și Velze (n. 5), p. 808

62 Idem, p. 808-809

63 Hotărârea din 4 octombrie 2011, Football Association Premier League și alții, C-403/08, EU:C:2011:631, Hotărârea din 13 octombrie 2011, Airfield și Canal Digitaal, C-431/09, EU:C:2011:648.

${ }^{64}$ Hotărârea din 7 martie 2013, ITV Broadcasting și alții, C-607/11, EU:C:2013:147

${ }^{65}$ Idem, pct. 8-10

66 Întrebările în forma lor originală se regăsesc la pct. 18 al Hotărârii:

1) Dreptul de a autoriza sau de a interzice "comunicarea publică a operelor lor, prin cablu sau fără cablu», prevăzut la articolul 3 alineatul (1) din Directiva [2001/29], este aplicabil în cazul în care:

a) autorii autorizează includerea operelor lor în programe televizate cu acces liber difuzate pe cale terestră, destinate recepționării fie pe teritoriul unui stat membru, fie într-o zonă geografică determinată a unui stat membru;

b) un terț (și anume un organism care nu este organismul de radiodifuziune sau de televiziune inițial) furnizează un serviciu prin care abonații individuali din zona de recepție a programelor, care pot recepționa în mod legal programele la un aparat receptor de televiziune în locuințele lor, se pot conecta la serverul terțului și pot recepționa conținutul programului în flux continuu prin internet?

2) În vederea răspunsului la prima întrebare, este relevant dacă:

a) serverul terțului permite numai o conectare «individuală» pentru fiecare abonat, prin care fiecare abonat stabilește propria conexiune internet la server, iar fiecare pachet de date transmis de server prin internet se adresează unui singur abonat individual?

b) serviciul furnizat de terț este finanțat prin publicitate, care este prezentată pre-roll (și anume în intervalul de timp de după conectarea unui abonat, dar înainte ca acesta să înceapă să recepționeze conținutul programului) sau in-skin (și anume în cadrul softului de vizualizare care afișează programul 
recepționat pe dispozitivul de vizualizare al abonatului, dar în afara imaginii programului), dar publicitatea originală cuprinsă în program este prezentată abonatului acolo unde este inserată în program de organismul de radiodifuziune sau de televiziune?

c) organismul care intervine:

i) furnizează un serviciu alternativ în raport cu serviciul furnizat de organismul de radiodifuziune sau de televiziune inițial, acționând astfel în concurență directă cu organismul de radiodifuziune sau de televiziune inițial în ceea ce privește atragerea audienței sau

ii) acționând în concurență directă cu organismul de radiodifuziune sau de televiziune inițial în ceea ce privește veniturile obținute din publicitate?

${ }^{67}$ TvCatchup (n. 64), pct. 37

68 Idem, pct. 38

${ }^{69}$ idem, pct. 39

${ }^{70}$ A se vedea Hugenholtz și Velze, p. 805, Ficsor (n. 52), Mira Burri, Permission to Link. Making Available via Hyperlinks in the European Union after Svensson, 2014, http://www.jipitec.eu/issues/jipitec-5-32014/4098 (accesat la 28.06.2017, ora 18:00)

${ }^{71}$ FAPL (n.63)

72 Huggenoltz și Velze (n. 5), p. 805

73 În același sens a se vedea Ficsor (n. 52),p. 20

${ }^{74}$ Hugenholtz și Velze (n. 5), p. 806

75 ALAl, Opinion Proposed to the Executive Committee and adopted at its meeting, 17 September 2014 on the criterion "New Public", developed by the Court of Justice of the European Union (CJEU), put in the context of making available and communication to the public, http://www.alai.org/ en/assets/files/resolutions/2014-opinion-new-public.pdf (accesat la 26.06.2017, 16:08), p. 14

${ }^{76}$ Idem, p. 21

77 Mihály Ficsor, Svensson and the CJEU'S "new public"theory: what the E.U.may learn from the U.S. to avoid judicial lapses, http://fordhamipconference.com/wp-content/uploads/2015/04/UpdateFicsor-Mihaly-3B-Copyright-Session-3B_Ficsor_Svensson_from_new-angles.pdf (accesată la data de 23.06.2017, ora 13:25), p. 2

${ }^{78}$ Hugenholtz și Velze (n. 5), p. 811

${ }^{79}$ Velze (n. 3), p. 76

80 Ordonanța din 21 octombrie 2014, BestWater International, C-348/13, EU:C:2014:2315, pct. 4-10

81 Idem, pct. 11

${ }^{82}$ Articolul 99 din Regulamentul de procedură al Curții de Justiție din 25 septembrie 2012: „Atunci când o întrebare formulată cu titlu preliminar este identică cu o întrebare asupra căreia Curtea s-a pronunțat deja, atunci când răspunsul la o astfel de întrebare poate fi în mod clar dedus din jurisprudență sau atunci când răspunsul la întrebarea formulată cu titlu preliminar nu lasă loc niciunei îndoieli rezonabile, Curtea, la propunerea judecătorului raportor și după ascultarea avocatului general, poate oricând să decidă să se pronunțe prin ordonanță motivată.

${ }^{83}$ BestWater (n. 80), pct. 20

${ }^{84} \mathrm{~A}$ se vedea ALAl, 2013 (n. 12), p. 2 și urm.

${ }^{85}$ Hotărârea din 8 septembrie 2016, GS Media, C-160/15, EU:C:2016:644, pct. 24

${ }^{86}$ Idem., pct. 26

87 Idem., pct. 37, 41 și urm.

88 Idem., pct. 42

89 Idem., pct. 37

${ }^{90}$ Idem., pct. 35 
${ }^{91}$ Idem., pct. 49

92 Idem., pct. 45-46

${ }^{93}$ Mihály J. Ficsor, GS Media and Soulier - may the hyperlink conundrum be solved and the "new public", "specific technical means" and "restricted access" theories be neutralized through the application of the implied licence doctrine and the innocent infringement defense)?, http://www.copyrightseesaw.net/archive/?sw_10_item=73 (accesat la 27.06.21:00), p. 6

${ }^{94}$ GS Media (n. 85), pct. 51

${ }^{95}$ Curtea a reinterpretat de fapt jurisprudența sa din BestWater, susținând că acea cauză se referă la postarea operelor cu autorizarea titularilor de drept, cu toate că din starea de fapt a cauzei reiese contrariul. A se vedea pct. 41 din hotărârea GS Media.

${ }^{96}$ Tomasz Targosz, A New Chapter in the Linking Saga, http://kluwercopyrightblog.com/2016/09/09/anew-chapter-in-the-linking-saga-its-becoming-a-horror/ (accesat la 27.06.2017.,ora 18:02)

${ }_{97}$ Concluziile prezentate la 7 aprilie 2016, GS Media, C-160/15, EU:C:2016:221, pct. 78

${ }^{98}$ Ficsor (n. 93), p. 6

${ }^{99}$ A se vedea par. 38 din GS Media (n. 85)

${ }^{100}$ Această cauză avea ca și obiect interpretarea prin trimitere preliminară a articolului 8 alineatul (2) din directiva 92/100/CEE privind dreptul de închiriere și de împrumut și anumite drepturi conexe dreptului de autor în domeniul proprietății intelectuale. Curtea a menționat în mod expres, că noțiunea de „comunicare publică" utilizată în cadrul articolului 3 alineatul (1) din Directiva 2001/29 nu corespunde cu noțiunea aferentă articolului 8 alineatul (2) din Directiva 92/100 din moment ce ele sunt utilizate ,în contexte care nu sunt identice și privesc finalități care, deși sunt, desigur, similare, sunt totuși parțial divergente." În urma hotărârii din din 31 mai 2016, Reha Trening, C-117/15, EU:C:2016:379, în special concluziile din par. 31, considerăm însă, că această diferențiere este retrasă de Curte.

101 Hotărârea din 31 mai 2016, Reha Training, C-117/15, EU:C:2016:379

102 Idem, par. 64

${ }^{103}$ Ficsor (. 93), p. 6

${ }^{104}$ A se vedea, de exemplu, opiniile contrare ale celor două organizații specializate în dreptul de autor, ALAI și SEDA, menționate mai sus.

105 Jane Ginsburg propune să se înlocuiască criterul „noului public” cu licența implicită, care, pe de o parte, salvează internetul, dar totodată, asigură o separare strictă între comunicarea publică făcută cu autorizarea titularului de drept, respectiv cea fără autorizare. Pentru detalii a se vedea Burri (.70), p.252 Aceeași soluție este dezvoltată și de Ficsor, care argumentează că în lumina hotărârii din 16 noiembrie 2016, Soulier și Doke, C-301/15, EU:C:2016:878 și Curtea de Justiție a Uniunii Europene pare să se ralieze acestei opinii. Suntem reticenți cu privire la această presupunere, însă apreciam modul sugestiv al autorului de îndruma Curtea către o soluție mai compatibilă cu dreptul de autor. Pentru detalii a se vedea Ficsor (n. 93) p. 8 și urm. Licența implicită este însă abandonată de ALAI. Pentru detalii, a se vedea ALAl, ALAI Report and Opinion on a Berne-compatible reconciliation of hyperlinking and the communication to the public right on the internet, 2015, http://www.alai.org/en/assets/files/resolutions/201503-hyperlinking-report-andopinion-2.pdf (accesat la 29.06.2017, ora 10:29), p. 2

${ }^{106}$ Aceste soluții sunt propuse de ALAl. Fiecare dintre aceste soluții presupune însă intervenția titularilor de drepturi, a administratorului sau a legiuitorului. Pentru detalii, a se vedea ALAI, 2015, p. 4 și urm.

${ }^{107}$ Această interpretare fost consacrată în jurisprudența instanțelor naționale din Statele Unite, dar care a fost ulterior abandonată din cauză că a condus la rezultate inechitabile. Pentru detalii, a se vedea Andrea Tóth, A linkelés jelene és jövője az Egyesült Államok és az Európai Unió joggyakorlata alapján în Iparjogvédelmi és Szerzői Jogi Szemle 1/2016, p. 64 și urm. 